\title{
わが国沿岸海域に分布する砂質堆積物について*
}

\author{
大 嶋 和 雄**
}

\section{1. ‘ばめに}

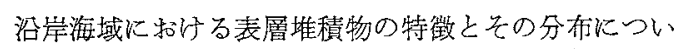
ての系統的な研究は，斉一説の立場から，ドイッ北海の Senckenberg-am-Meer に求いて1920年代飞始った(早圾， 1964)。艺の後, 現世堆積物についての知識が，不油鉱 床探查指針として有効であるという認識から，海底堆積 物についての研究やシンポシウムの報告集は，TRASK (1939)以来, 数多く出版されてさた(REINECK \& SINGH, 1973; RICHARD, 1978 等)。また, 堆積学の㐫用として は，堆積物そのものを工事対象亡する土木，建築等の分 野から土質工学が発達していった。さらに，海望侵食や 漂砂等の研究が進展し, わが国の海岸工学の業績が, 国 際的な堆積学の教科書に数多く引用されている。また， 海砂利についての堆積学的な調查も進わられている（有 田1981)。

わが国沿岸海域は，世界でも有数の海場として䦕発さ れ，従来から高度に利用さ祅てきた。そして，第二の主 要な用途は, 漁場利用と競合する臨海工羓用地, 空港, 船船基地等の理立て用地としてである。とくに，東京海 や瀬戸内海等の臨海工業地带での埋立て工事は進み，自 然海浜状態の海岸線は50\%以下となっている。この沿岸 開発に信い，沿岸都市下水や産業排水中に含委水る大量 の有機物が閉鎖性海域に流入するため，沿岸海水の慢性 的な富栄養化と赤潮の発生, 沈積した浾潮遺䯚の分解に 原因するへド懂大な社会問題となっている。この ような沿岸環境問題に対して, 効果的な対応を困るには, 海洋地質学だけではなく, 海洋物理学, 海洋化学, 水産 学, 海岸工学等々の学祭的な共同研究が必要である。わ が国では，環境庁の研究調整のもとに，沿岸環境につい ての学際的な共同研究汃進められつつある。とくに，海 洋物理学分野の海洋観測データと，その数值計算結果に 基づく承理モデルによって，堆積物の運搬や拡散系を推 定することも可能になってきた。をた，海水と堆穦物と の間の物質双支は，海洋化学的に解析され，水産生物学

* 昭和61年 6 月 4 日第51国石油技街拹会総会，地誓・探鉣部阴シンポジ りムにて䛾演

** 焎質調査所
的には，大型ベントスの定量的な分布調查もされるな ど，沿岸環境の実態が，総合的に明か儿されつらある。 すなるわ，地暂学の分野たけでは，把握することのでき なかった環境の実態が，上り明かにされるとともに，堆 積環境についての認識む，一段と深まってきた。

沿岸環境管理業務に括汁る堆積物謂査の主要な役割 は，次の 2 点にある。

1. 沿岸堆積環境因子としての地形, 底質の諸要素 （堆積楧造，粒度組成，秒粒組成，重鉱物組成，遺 駭群集等)の特徵と久の分布を記載し，それら因子 の相互関係を解析することによって，堆積環境の診 断を行ら。

2. 堆積環境に搬入执よび，そこから搬出される物質 収支を定量化することによって，地史的な立場から の環璄容量を求める。

本文は, 環境庘のプロシェクト研究として, 日本沿岸 各地の堆積物の調査研究を行ってきた結果から，沿岸堆 積物の特徴を概説するものである。堆積物の特诖を解明 与るとは, 何が (粒度, 地質), 何処から (起源：砂粒や 重鉱物組成)，何時（季節，時代）,どのようにして（運 搬様式), 何処に（空間的な広がり）ぞれくらいの割合

（准積構造, $\mathrm{Pb}-210$ 年代㵋定) で隻積し，その推積物は どらなるか（再移動，滞留，残留），また，ベントスの 生息底質として，どのような影響を与えているのかを明 らかにすることであると考光る。

\section{2. 沿岸海域における堆皘作用の概念}

本論で取り扱う沿岸海域とは, 沿岸水和上び波浪によ って物質が運搬される範囲, 海岸線から大陸棚外縁（水 深一 $120 \pm 20 \mathrm{~m}$ ）玉でを言う。大陸棚上の碚屑物の分布 についての代表的なモデルを最初に提起したのは, JOHN SON (1919) である。JOHNSON (1919) は，大陸棚海底 地形とそれを覆う海水の運動との間には, 力学的な平衝

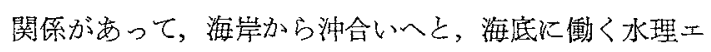
ネルギーの減少に伴い，堆積物の粒径は細粒化（砂から 泥へ）して行くものと考竞た。JOHNSON モデルでの海 底推積物の主要な起源は, 河川供給物よりも沿岸侵食に さるるのの汪らが大きいと考克られていた。しかし， 


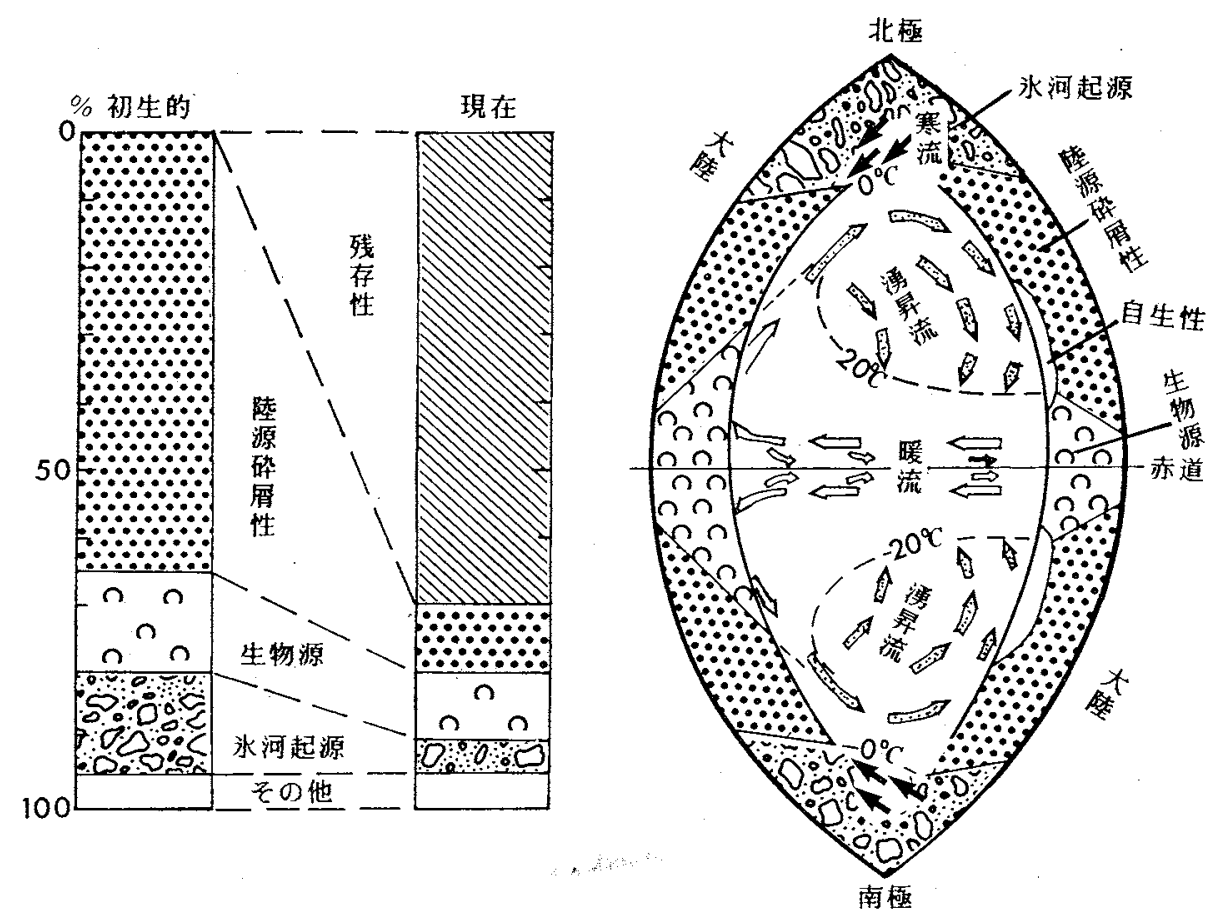

図 1 大陸棚堆積物の模式分布 EMERY (1968) k一部加筆

SHEPARD (1932) は，世界の大陸棚上の底質分有を検討 するなかで，堆積物の粒径は，涫合いに向かって細粒化 すると言らよりあ，いろんな堆積物が，モザイク状に複 雑に分布していることに注目した。そして，モザイク状 に分布する粗粒堆積物は，現在堆積物と言与上りる; 氷 期の海面低下時に堆穦した物と考えた方が良いと考觉 た。この考光は，EMERY (1952，1968) によって，大 陸梌の残存堆積物分布という新しい概念に発展さ世られ た。

EMERY (1968)は, 大陸棚上の堆積物を, 次の五つに 分類した：1. 自生性 (海緑石，燐灰石等），2.生物源泩 (有孔虫, 貝類の殸)，3. 残留性（海底岩盤類の侵食残 留物)，4. 残存性（低海面期の海浜付近の堆積物）， 5 . 确首性（水流，風，水河作用等の現在営力によって海中 に供給される砕屑物)。そして，陸上の土壤分布が，気 候带に支配されているよらに，沿岸海底堆䅌物の初生的 な分布は，海流や沿岸気候によって支配される。すなわ ち，赤道周辺には生物源のサンゴ礁構成物や貝殸砂が発 達し，大陸氷河の縁辺域には氷河性堆積物が分布し，そ の他の大部分には，陸源䂶屑性堆積物が分布している （図 1)。この初生的な堆積物分布方，第四紀後期の海面 变動に伴ら水理環境変化によって変元られ, 現在の大陸 棚表面の約70\%は，残存堆積物によって覆われていると 推定した。
第三のモデルは，JOHNSON (1919) および EMERY (1968) 双方の要素を合体して作られたものである (SWIFT et al. 1972)。海岸線の移動T(海進客たは海退) は, 沿岸に供給さ礼る堆積物量 $S$, 堆積物の特性 $G$ (粒 径礼よび比重)，沿岸水理ェネルギーE（波浪和よび沿 岸流）の大ささ，相詨的な海面変化量 $R$ 叔よび沿岸海底 地形勾配 $L$ 等の因子の相互関系によって表現できる。

$$
S G / E-R / L \propto T
$$

第一項 $S G / E$ は，沿岸海域での有効浣積量を示す。 すなわら， $S$ の増加は，沿岸海域への堆積物の供給量の 増大を示し，粒径Gの増大心，再移動されにくい粒径成 分の璔大に対応する。そして，水理工ネルギーEの增大 は，堆積物の再移動，拡散の原因々なるので，沿岸沈積 量に反比例与る。第 2 項 $R / L$ は, 海面変動に対応する。 $R$ は，海面変動（旅河性または棈造性）量を示し，上昇 は正，下降は負の值を取る。海岸付近の地形傾斜 $L$ が さけ扎ば，海岸線の水应移動量は小さくなる。逆に，L が小さければ(平野)，その水平移動量は大さくなる。T の符号は，陸方向(海進時) の移動には負，海方向（海 退時）には正となる。すなわち，海紫線の位置は，承河 性海面変動々地域的な堆積量収支によって決定される。

以上のよらに，沿岸堆積物の性格は，海岸線の移動を 支配する氷河性海面変動によって，基本的に支配されて いることが理解できる。 


\section{3. 最終水期以降の海面変動}

湊（1966）は，涾河性海面変動にとむなって形成され た大陸棚上の海峡地形には，その海峡が形成されて以降 の海面变動過程が，侵食地形として残されていることに

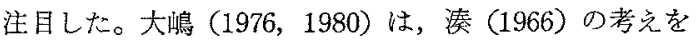
発展させて，日本列島の島々を分断する主な海峡の各水 深と，その水深に対応する海峡岩艋地形の最子㢸い輻と の関係について検討した。その理由は, 各低位海水準に お汀る潮流・海流の侵食営力を，最も強く反映している のは，海水の通過する海快最小断面積であると考えたか らである。海峡断面積は，(海峡の楅） $\times$ (海峡の深度) /2の三角形で近似される。海陕の深度は，海水集位に 対応するから，海峡断面積は，海陕蝠の函数となる。し たがって，海峡断面積変化は，海陕幅の変化で表現する ことがでさる。すなわら，海峡を通過する海水量と海峡 断面積とが平衡に達した時の流速の速い表層流の沿岸侵 食によって形成された海峡幅を求めることによって，当 時の海水準が，推定されると仮定する。この仮定が正し いとすると，各海峡の水樑と幅との間には，同じような 潮流侵食作用の変化過程が記録されている筈である。そ こで，海峡の各水深に対応する最も狭い海峡幅を，海底 露岩地形図から読み取って，図 2 を作成した。

海峡の水深を $Y$, 水深 $Y$ に対応する海陕最小幅を $X$ と すると，海陕の水深と幅との関係は，次の式で表され る。

$$
Y=a X-b
$$

$a$ : 海峡の幅増大係数, $b$ : 海峡最狭部の最大水深。 $Y=0$ でのXは，現海面での海峡最小幅を表し， $X=$ 0 での $Y$ は，海峡鞍部の水深を示す。

海峡の水深と幅との関係は，折れ線グラフで表現され るょうに，幾つかの㑯斜変换点が努る。变換点の水樑 は， $-100 \mathrm{~m} ，-80 \mathrm{~m},-60 \mathrm{~m} ，-45 \mathrm{~m}$ に見られる。し たがって，大陸棚を侵食する海睠が形成されて以降の比 較的長い海面停滞は， $-100 \pm 10 \mathrm{~m} ，-80 \pm 5 \mathrm{~m},-60$ $\pm 5 \mathrm{~m},-45 \pm 5 \mathrm{~m}$ にったことが読み取れる。

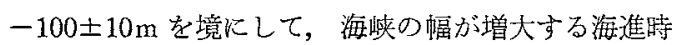
の側方侵食は，朝鮮，対䭴，大隅和よび津軽の 4 つの海 峡に共通してみられる。現河川でる，河川水量の增大に よって平地に氾濫が起こると，河幅が一気に抬大するよ らに，海面上昇に伴なって海峡が形成された当初は，海 睠幅が一気に拡大さ吼らる。すなわら， $a$ の值の小さ いのは，形成当初の海峡幅拢大状沇を反映するものであ る。このよらな特幑は, 海水準位一 $45 \pm 5 \mathrm{~m}$ を境にして 新たに海陕となった五島灘，宗谷海陕等にも共通してみ られる。

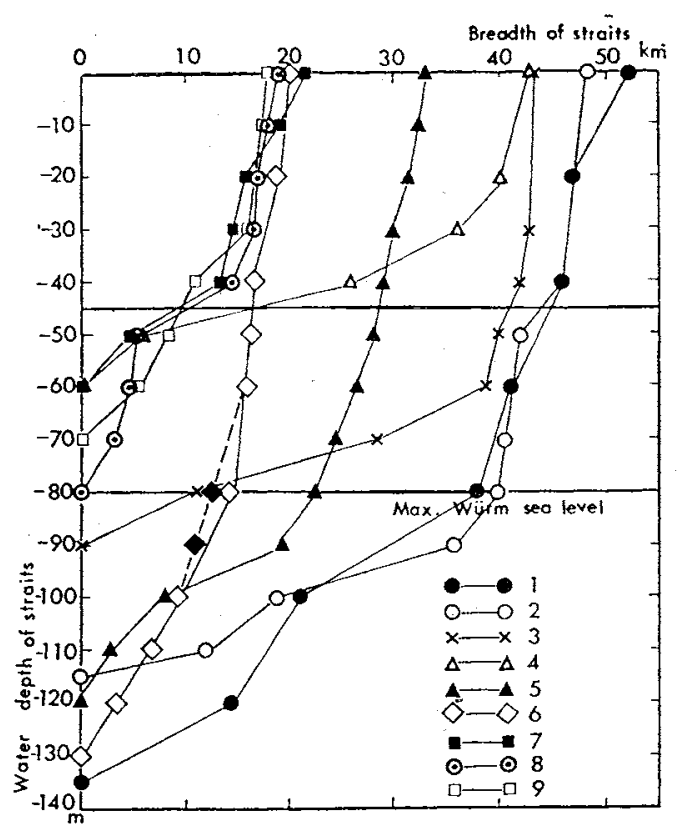

図 2 海峡の水深々最短幅との臨係, 大嶋 (1980)

1. 朝鮮海快, 2. 対馬海蚗, 3. 隐岐海峡, 4. 宗谷海峡, 5. 大隅海峡, 6. 津軽海侠, 7. 焼尻水道, 8. 西海眣, 9. 種子島海屼

それに対して，海面低下に対応する侵食地形は，側方 よりも下方に進む。河川の水位が，水路内で低下する場 合，河幅が一気に狭くなるのではなく，汇濫原に対する 垂直侵食地形として現れる。- $80 \pm 5 \mathrm{~m}$ 几の勾配の大き

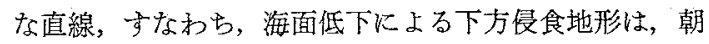
鮮，対馬，津軽および大隅の4つの海狭炕共通して認め られる。この特徴から，これらの海峡が形成されて以降

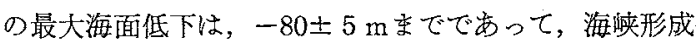
後，二度と陸化したことがなかったことな示している。

これら低海面の時期については，わが国周辺の大陸棚 や，海岸平野地下から採取した貝款や泥炭の採取深度と その放射性炭素年代測定值とから求めることができる。 ある時代の海水準位は，その时代に形成された海岸平野 の低位泥炭層と仼济同一レベルにあり，貝殸やサンゴ礁 よりも上万に位置するといら基準によって推定される。 㘠 3から求わられる最低海水準は, $-80 \pm 10 \mathrm{~m}$ で,その年 代は $18,000 \pm 1,000$ 年前である。また，宗谷海陝を始めと

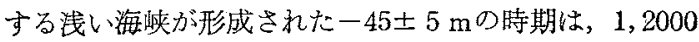
$\pm 1,000$ 年前と読み取れる。

\section{4. 沿岸海域に分布する砂質堆皘物}

沿岸堆積環境は，海岸線の移動とともに発達してきた ものでめる。とくに，最終水期以降の海面変動亡海岸線 


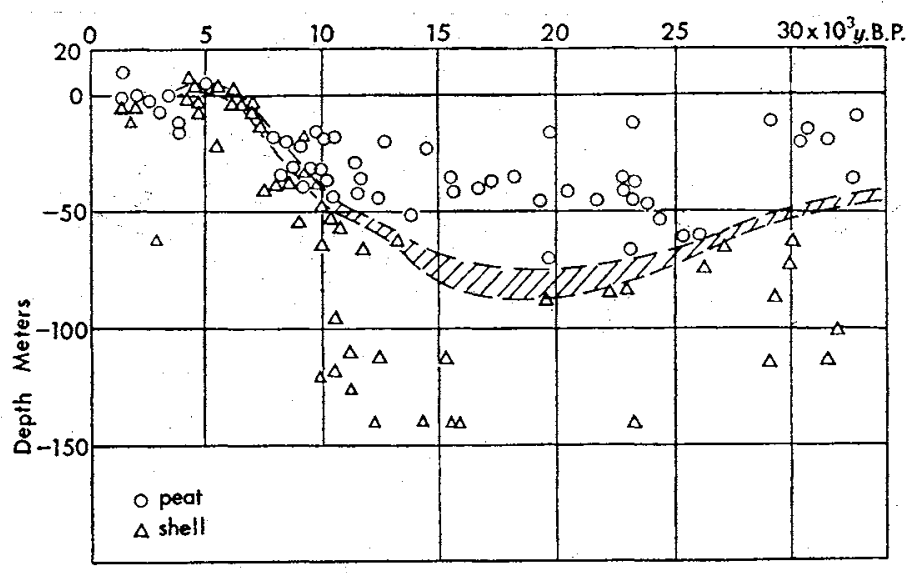

図 3 第四紀後期以降の海水準変動 大嶋 (1980)

表 1 沿岸堆積環境区分

\begin{tabular}{|c|c|c|c|}
\hline 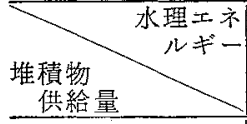 & 大 & 中 & 小 \\
\hline 大 & $\begin{array}{l}\text { 仙台湾, } \\
\text { 富山湾 }\end{array}$ & 石犿湾 & $\begin{array}{l}\text { 大阪湾, } \\
\text { 查京湾 }\end{array}$ \\
\hline 小 & $\begin{array}{l}\text { 対馬周辺海 } \\
\text { 域 }\end{array}$ & 噴火湾 & $\begin{array}{l}\text { 伊予灘, } \\
\text { 周防灘 }\end{array}$ \\
\hline
\end{tabular}

を構成する地質特性が，海岸地形の基本的な骨格を形成 してきた。また，堆積物の分有は，堆積盆に供給される 堆積物量とその特徽拉よび邁搬を支配する水理圷ルギ 一によって決められる。わが国の沿岸堆積環境は，堆積 物供給量と水理エネルギーとによって，大きく6つに区 分できる(表 1)。衣の各々について, 概説する。

\section{1 仙台湾}

仙台湾大陸棚は, 外縁水深 $140-155 \mathrm{~m}$, 最大幅70 km, 平均傾斜は $150 \mathrm{~m} / 70 \mathrm{~km}=8$ 分で，非常に平坦である。 しかし，北上川河口から $150 \mathrm{~km}$ 以上流飞位置する沛積 平野の標高は約 $100 \mathrm{~m}$ であって，沖積平野の平均公配は， 大陸棚のとれよりもはるかに平坦である(長谷，1967）。 したがって，海面が約 $3 \mathrm{~m}$ 上昇した䋥文海進時の海岸線 は，北上平野の内陸約 $35 \mathrm{~km}$ まで入り込んだが，最終水 期の $80 \mathrm{~m}$ 海面低下時の海岸線は，大陸棚上を約 $40 \mathrm{~km}$ 後 退したにすぎない。

仙台湾沿岸の波浪侵食, 漂砂の影響域は距岸 $1 \mathrm{~km}$, 水 深 $15 \mathrm{~m}$ 付近で見られる。その傾斜は， $15 \mathrm{~m} / 1 \mathrm{~km}=50$ 分で，似台湾大陸榞の平均傾斜上りも6 倍子大きいが， 外洋に面した石狩湾沿岸砂州地形の勾配とほ注等しい。 現海水準の水理営力で形成される $-40 \mathrm{~m}$ 以浅の海底地形 は，比較的勾配の大きな $0-15 \mathrm{~m}$ 海浜域と， $-15 \mathrm{~m}$ か らー40mの平坦な面からなる。そして，海岸から油合い
に向かっての水理エネルギーの減少に対応して, 砂から 泥へ之粒径分化している嫶積物が，現世堆積物である。 現世堆樍物の主たる分布水深は, 沿宸の水理エネルギー の大きさによってる異なるが，一般には，砂は0から15 $\mathrm{m} ，$ 泥は10から40mである。しかし，水深 $40 \mathrm{~m}$ から 140 $\mathrm{m}$ の大陸棚表面の大部分は, 現在の承理エネルギー環境 では，陸域から運搬されて来ない粗粒の残存堆積物によ って覆われている。このような残存堆積物が、大陸棚上を 広く覆っている理由としては, 約 18,000 年前から7,000 年前までの間に，急激に海面が上昇したことが挙げられ る。この海面変化は, 沿岸域での堆䡠物供給量と海面上 昇速度との間に，平衡関係を形成するには，西要りに急 激で短かった。約 7,000 年前以降になって, 海面上昇速度 が荤くなり，ある程度の厚さをるつ倠積物が，大陸棚や 沿岸域に堆積することを可能にさせた。仙台湾沿岸での 現世堆積物の分布は，陸域から大量の土砂が供給される 北上川，名取川，阿武隈川等の河口域（最大層厚 $40 \mathrm{~m}$ ) に限られている。

日本の海岸平野の大部分は, 縄文海進後の海面停滞時 に形成された潟湖の埋立てによってできたものであるか ら, 現海岸線の形成は中部粘土層(5,000年前以前) の堆 積後である。仙台湾沿岸の後背地堆精物分有から, 現在 の仙台湾海岸線の形成は, 約3,000年前にさかのぼると推 定される。仙台湾での現世堆積物とは, 約7,000年前の現 海面達してからの堆積物をいう。また，現海岸線形成 後(約 3,000 年前以降)の堆積物を, 現在堆積物々定義す る。この現在堆積物の起源, 運搬経路, 堆積速度, お上 び再移動の実態を解明することが，唯積物収支研究の主 題である。

堆嫧環境因子のうち水深は地形環境を, 底質の温度分 布は, 沿岸水, 河川水, 親潮等の流況を反映する。酸化 還元電位の分布は，陸源有機物の供給量と分解量との関 


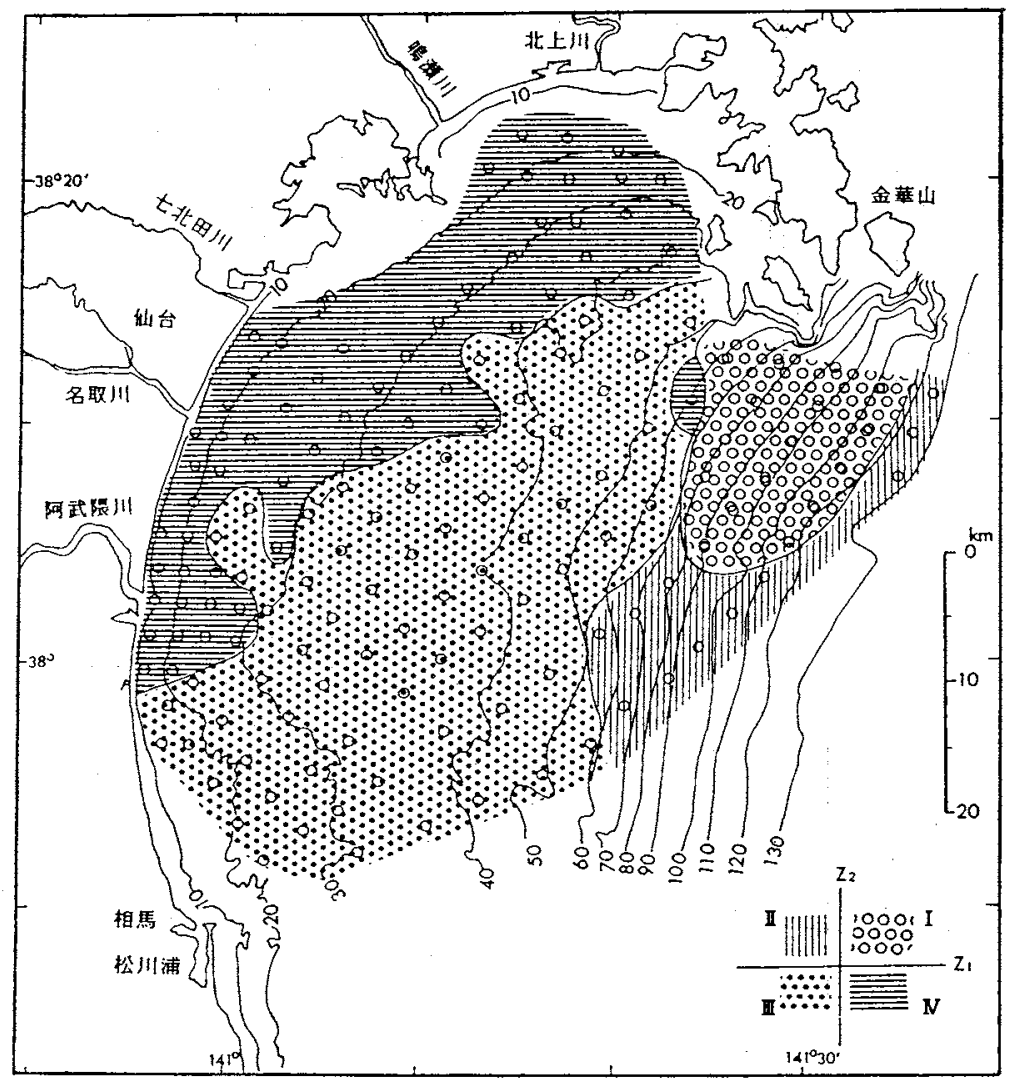

図 4 仙台湾環境因子の主成分分析による区分 大䳡ほか（1986）

係变たは，海洋生物生産量を反映している。堆積物の粒 度組成と堆積構造とは，運搬水流速度や堆積速度を示し ている。位台湾各採泥点に和ける，これらの環境因子デ 一夕の測定結果を，多变量解析（主成分分析）乙，その 因子負荷量（表 2) をもとに，仙台筫の環境区分図（図 4) を作成した。主成分分析のスコア分布（ $x$ 朝烧成 分 $1 ， y$ 軸に主成分 2 をとる）加，仙台湾は 4 つの環 境に区分でさる。

謤境 I は，主成分 $1 ， 2$ がとも化正であるから，水深 の深い, 堆積速度が比較的速い泥の谁積環境で, 沿岸水 と沖合い水との混合型環境ですある。環境目は，主成分 1 が負，主成分 2 が正であるから，水深は深く，底質の 温度が低い，推積速度の遅い仯の堆積環境で，外側大陸 棚沖合い水型環境である。環境杰は，主成分 $1 ， 2$ がと bに負て，砂啋分が多く，酸化還元電位が正の内側大陸 棚油合い水型環境で，堆積速度の遅い残存爑積物の分布 域に相当する。環境汹は，主成分 $1 か ゙$ 正，主成分 2 が負 であるから，承深が浅く，底質温度の高い，堆積速度の 速い泥の分布域で，沿岸水環境に相当する。

以上の堆積環境因子の解析結果から，仙台湾の現世堆 積物の沈積域としては，IVの沿岸水域拉よび】の潮目域
表 2 低台湾環境因子一因子負荷量 大彊汪

\begin{tabular}{|c|c|c|c|c|}
\hline 変 & & 量 & 主，成 文 1 & 主成，文 2 \\
\hline 水 & & 深 & -.0931 & .9177 \\
\hline$v$ & $\neq$ & 分 & -.3833 & -.2826 \\
\hline 砂 & & 分 & -.9084 & .0313 \\
\hline 泥 & & 分 & .9679 & .0532 \\
\hline 泥 & & 温 & .1601 & -.9126 \\
\hline & Eh & & -.8573 & -.0395 \\
\hline 軽 & $\mathrm{X}$ & 線 & .8601 & .077 \\
\hline
\end{tabular}

が就当するものと推定される。

仙台湾入の河川搬出物総量は，北上川，鳴瀨川，名取 川および阿武隈川から，年間平均数百万 $\mathrm{m}^{3}$ 以上儿達して いる。各河川河口周辺の堆積構造分布から，その一次的 な沈積域での琟積速度は，年間 10 数 $\mathrm{cm}$ 以上であると推 定される。しかし，似台湾沿岸には，内湾（松島湾, 万石 浦), 潟湖 (鳥の海, 松川浦) が，数千年間も埋積されず に残っているので，海岸地形発達史的には，めまり堆積 速度が速いとは見られない。表層堆積物の音波探查によ る層愿分布と，准積構造から推定される一次的な唯積速 度とを比較検討すると，現在堆積物の 8 割以上は外洋へ 


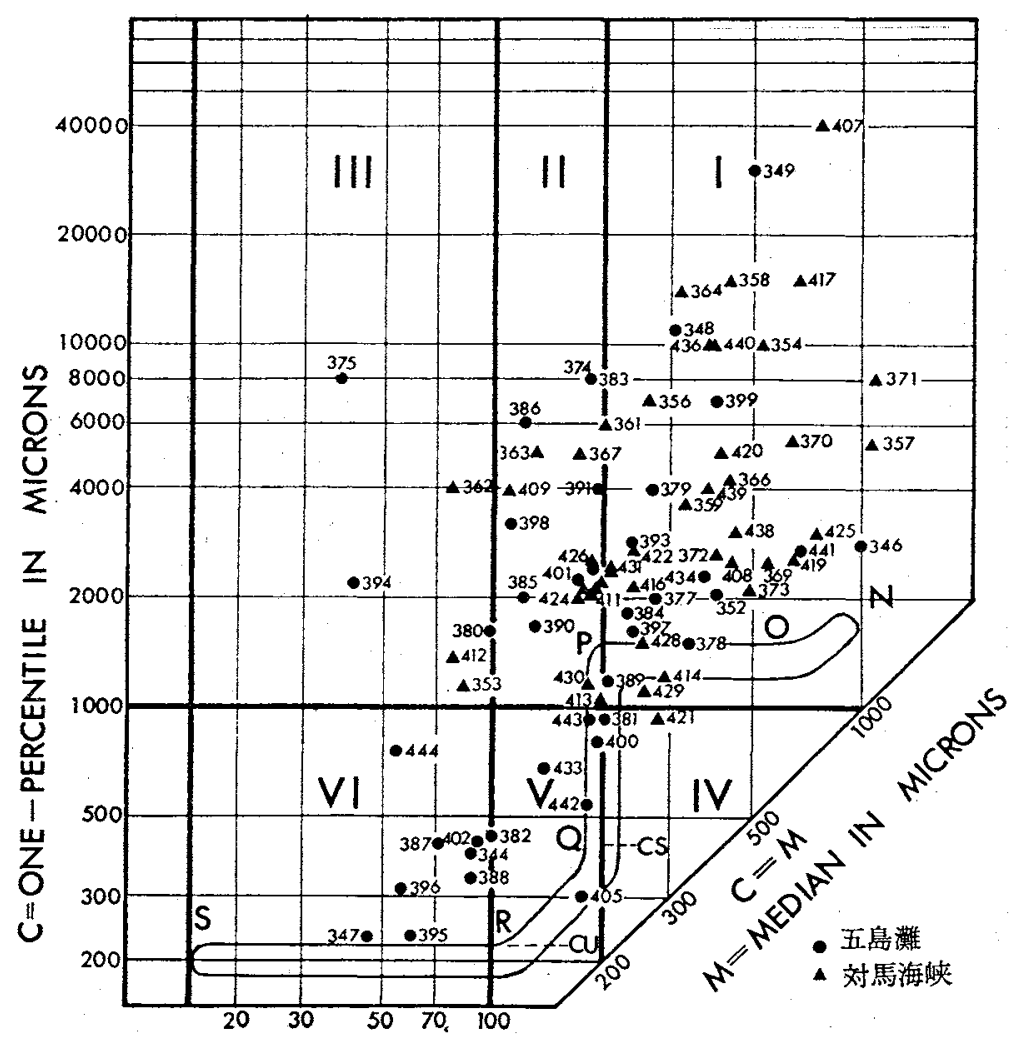

図 5 C-M パターンダイアグラム 大嶋ほか (1982)

抬散再移動されていると推計される。

\section{2 対馬周辺海域}

潮流速が 2 ノットに達する対馬海峡海底では, 一 110 〜 - $100 \mathrm{~m}$ 接峰面を浸食する海釜地形の延伸方向亡潮流 向とが一致している。また，九州から沖ノ島にかりての 90 100m 等深湶には，沿岸流によって形成される砂州 地形の特徵が見られる。すなわら，90m以樑の海底地形 形成には，現海況では考えられない，低海水準時の強い 潮流速の㗢いていたことが推定させられる。このよらな 潮流の速い海底には，現世堆積物の分布は，法とえぞみ られず，逆に，残存堆積物の再移動が顕著である。

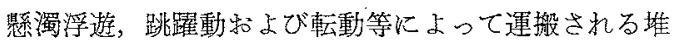
積物は，海岸線付近からの水理エネルギー減少に支配さ

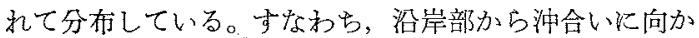
ら粗粒から細粒堆積物への带状配列である。この運搬形 態の差異を識別するために，C-M パターン図（図 5) が有効である(PASSEGA，1964)。Cは，最粗粒部から 重量で $1 \%$ 文での粒子の平均粘径で，最大運搬営力を反 映する。M以粒径中央值 (50\%径)て，平鸤運搬営力を 示す。掃流運搬堆積物は, 運搬の主営力の変化に対応し て，その粒度組成を変えて行く。 $\mathrm{C}-\mathrm{M}$ パターン図の各 成分記号は，次のような意味を乎っている。
$N / O$ ：転動堆積物， $O / P$ : 若千の㲘濁粒子を含さ転 動堆積物， $P / Q$ : 若干の 転動粒子を含を跳躍動堆積

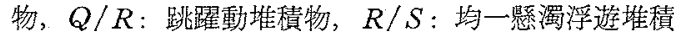
物，CS: 分級媓濁運搬される最大粒径，CU: 均一㲘 濁浮遊運搬される最大粒径

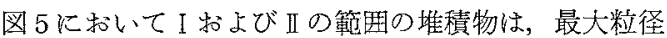
C>1 mm火よって区分されるもので，三として転動以 よって運搬された粒子からなり，㔠濁浮遊運搬はあまり 重要ではない。は，異なった水理営力炕よって運搬さ れた混合堆積物要たは，二層炕分れていた堆積物を混合

して分析したるのとも考克られる。

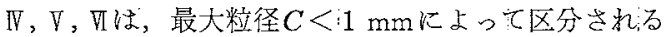
もので，主として懸濁浮遊おさび跳躃動運搬粒子とから なる。この C-M パターンのタイプを基準纪して，底質 図を作成した（図6）。九州沿㞥部には，四または四型 の懸濁浮遊運搬堆積物が分布する。五島灘では，水道部 を南下するにしたがって，潮流速の減少に半ら粒子の細 粒化（I $\rightarrow I I \rightarrow \nabla \rightarrow$ VI $)$ が認められる。対馬海陕の堆蝵

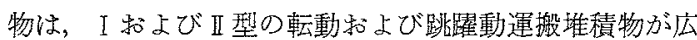
く分布し，陸源物質が供給されていないか，香たは洗積 しない状態にあることを示している。海峡部のI 型堆積 物は，残留もしくは残存堆積物，正型は再移動もしくは 


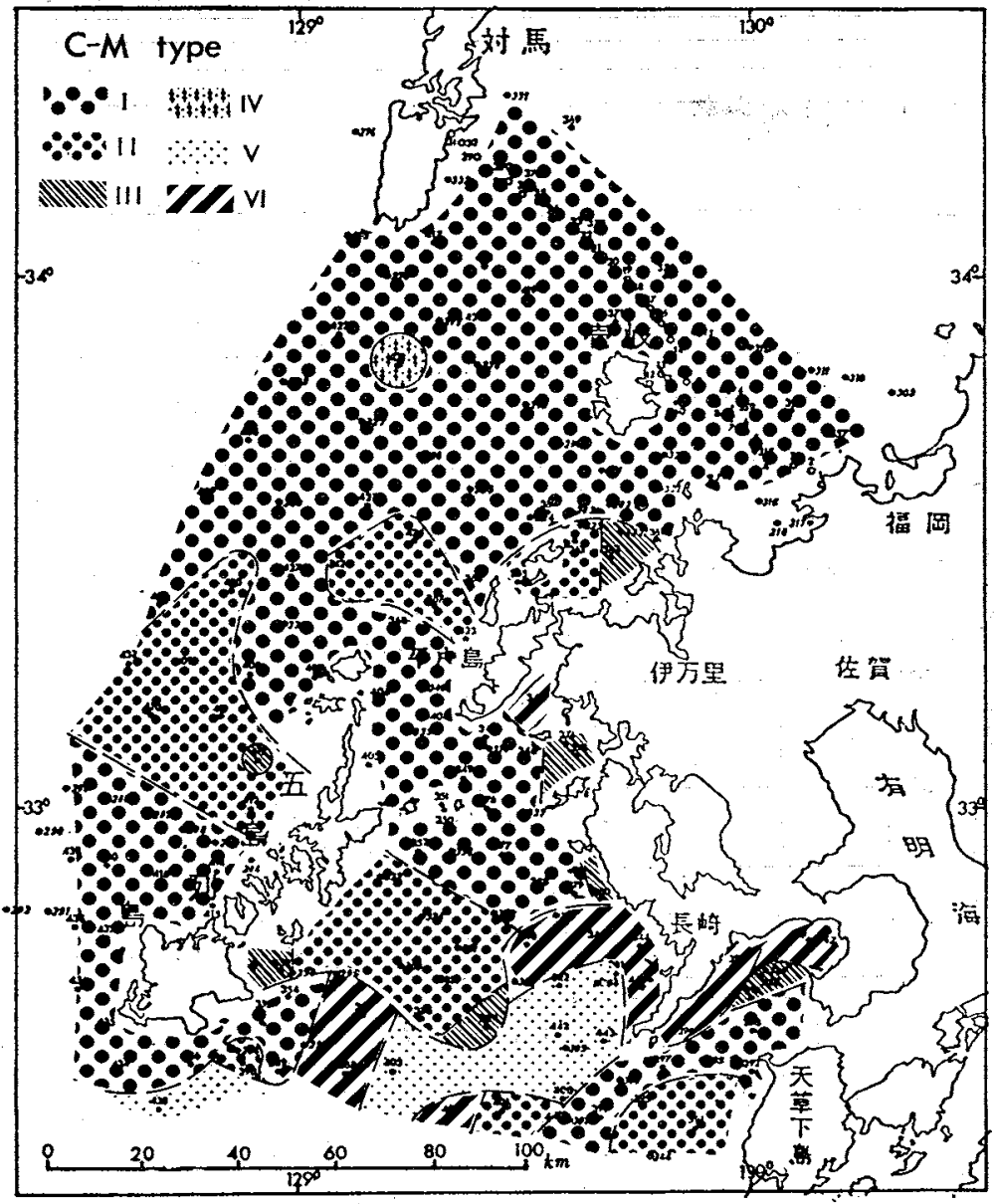

图 6 対馬周辺堆積物の C-M パターン分布図 大嶋ほか (1982)

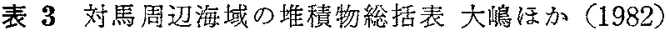

\begin{tabular}{|c|c|c|c|c|c|c|c|}
\hline & & 粒径中央値 & 淘 㑀 係 数 & 昰度係数 & $\begin{array}{c}\mathrm{C}-\mathrm{M} \\
\text { ハターン }\end{array}$ & 砂 䊀 組 成 & $\cdots$ \\
\hline 現 & 沿岸型 & $0 \sim 5 \phi$ & $0.7 \sim 2.4$ & $-0.4 \sim 0.4$ & $I, \mathbb{I I}, \nabla, \nabla$ & $\begin{array}{l}\text { 陸源性, 确屑性, } \\
\text { 現地性 }\end{array}$ & \\
\hline $\begin{array}{l}\text { 積 } \\
\text { 物 }\end{array}$ & 沖 合 型 & $3 \phi$ 以上 & 1 以上 & $0 \sim 0.7$ & V & 生物性, 䂶莌性, & \\
\hline $\begin{array}{l}\text { 残 } \\
\text { 存 } \\
\text { 推 }\end{array}$ & 再移動型 & $1 \sim 3 \phi$ & $\begin{array}{l}1.5 \text { 以下 } \\
1 \text { 边下多い }\end{array}$ & $0 \sim 0.2$ & $I, I I$ & $\begin{array}{l}\text { 告物性, 砕屏性, } \\
\text { 残存性 }\end{array}$ & サソドウェーブを作る \\
\hline 積 & 残 留 型 & $2 \phi$ 以下 & 1 以上 & $-0.6 \sim 0$ & $I, \mathbb{I}$ & $\begin{array}{l}\text { 生物性, 残存性, } \\
\text { 残留性 }\end{array}$ & $\begin{array}{l}\text { 砂嘴地形老作夕 } \\
\text { 浅海生貝化石を産す }\end{array}$ \\
\hline
\end{tabular}

残存堆積物と考兵られる。

粒度組成の特徵とその地形的分布から，現世堆積物之 残存堆積物とを識別することす可能である。この識別が 罗当か，否かは，この堆積物を構成する砂粒子の質的差 異から検討さ秃る。SHEPARD and MOORE (1954) 飞上 って始められた砂粒組成分析は，堆積物の起源を明らか
にする有効な手段である。砂粒子は；その起源から，砕 屑性, 火山性, 白生性, 生物源性, 残存性に区分され る。

本海域の堆積物は，その地形的な分布を基本として， 水深 $40 \mathrm{~m}$ 以浅に分布与万現世堆積物及び承深 $40 \mathrm{~m} \sim 140$ $\mathrm{m}$ の大陸棚を覆う残存堆積物に区分できる。そして，こ 


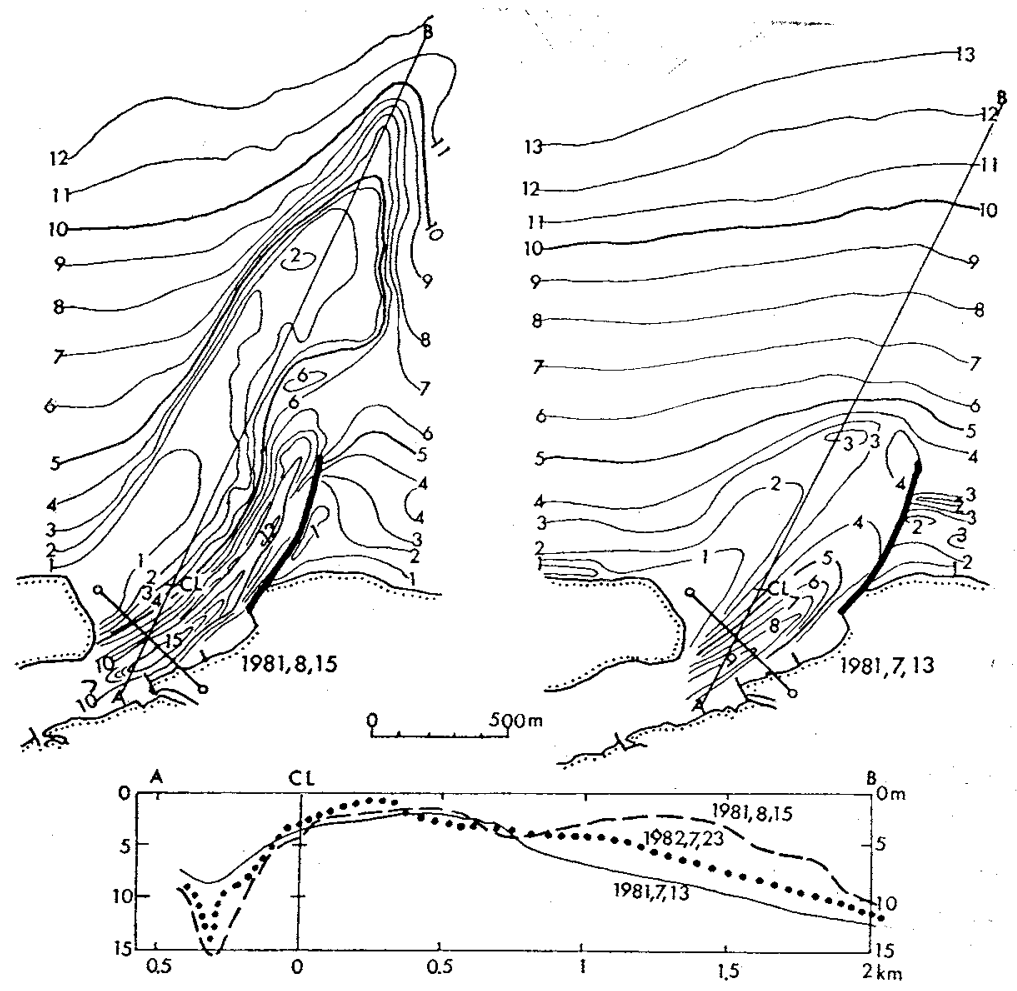

図 7 石狩川河口の洪水による地形变動 森田ほか (1982)

れらの准積物は，粒度組成と砂粒組成の特街から，現世 堆積物は沿岸型と沖合い型に，残存堆積物は残留型之再 移動型に細分される(表 3 )。

\section{3 石狩湾}

石狩湾大陸棚は，外縁水樑 $120 \pm 20 \mathrm{~m}$ ，最大幅 $52 \mathrm{~km}$ に達する。現海水準で形成されるー $38 \mathrm{~m}$ 以浅の海底地形 は，0〜ー10 mの沿岸砂州带，多少㑯斜の異なるー10〜 $-20 \mathrm{~m}$ と $-20 \sim-38 \mathrm{~m}$ の泥質平坦面とからなる。一 $20 \sim$ $-38 \mathrm{~m}$ 面法, 現在泥質堆積物の主たる沈積域に相当す る。この石狩浮住ぐ石狩川は, 年平均, 浮遊土砂 150

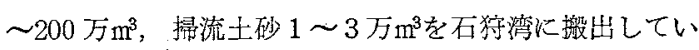
る。掃流土砂は, 河口付近に沈積して河口変動の大きな 原因となっている。また, 浮遊土砂は, 石狩川河口のみ ならず，広く湾内外に拡散しているものと考えられる。 本海域での堆積物の再移動量を示す例として，1981年 8 月 3 日の洪水による河口地形変化に読み取ることがでさ

\section{る(図 7)。}

洪水前（7月13日）々洪水後（8月15日）の河口地形 を比較すると，河口の導流堤先端付近をでは，洪水流に よって洗掘浸食され，そこから約 $1,500 \mathrm{~m}$ 先まで舌状に 砂州が延びている。そして，洪水前の水深 $10 \mathrm{~m}$ の海底 が，2 $\mathrm{m}$ 浅くなった。この洪水に上る河口部の洗掘
土砂量は 90 万 $\mathrm{m}^{3}$ ，堆積量が 350 万 $\mathrm{m}^{3} て ゙$ って，石狩川の 年間平均搬出土砂総量とほ济同じ 260 万 $\mathrm{m}^{3}$ が河口周辺だ ケで堆積したことになる。さらにこの河口周辺に堆積 した土砂の半分以上が，翌年（1982年 7 月 23 日）をで代 再移動したことが，地形断面変化から読文取れる。すな わ⿱ わ，1年後には，その大半が再移動し，3000年来続い てきた水理条件に平衡する海岸線之海底地形に復元され ている。これらの再移動された土砂は，大陸棚広く拡 散されるものと推定される。その過程は，表層堆積物の 軟X線写真による堆積構造から読み取ることができる。

軟X線写真で観察される堆積棈造は, 次の 4 つに区別 される。規則型(粒度扎よび色調の異なる層厚 $5 \mathrm{~cm}$ 以下 の薄層が互層する。各薄層每の粒度組成は均一である), 不規則型（規則型の互層が，生物活動，波浪执よび沿岸 流で乱され，再移動しつつある。の），均一型(生物活 動の痘跡恃残されているが，葉理は認められない，㴽注 均一な砂をたは泥）および溥層型（海底下 $10 \mathrm{~cm}$ 以内に, 基盤が存在するもの)である。これらの堆積構造型は, 大陸棚上の水理環境に対応して，規則正しく分布してい る(図 8)。

規則型の分布は，主として，石附川からその北側に限 られ，河川から搬入された浮遊䍹濁運搬物の一次的沈積 


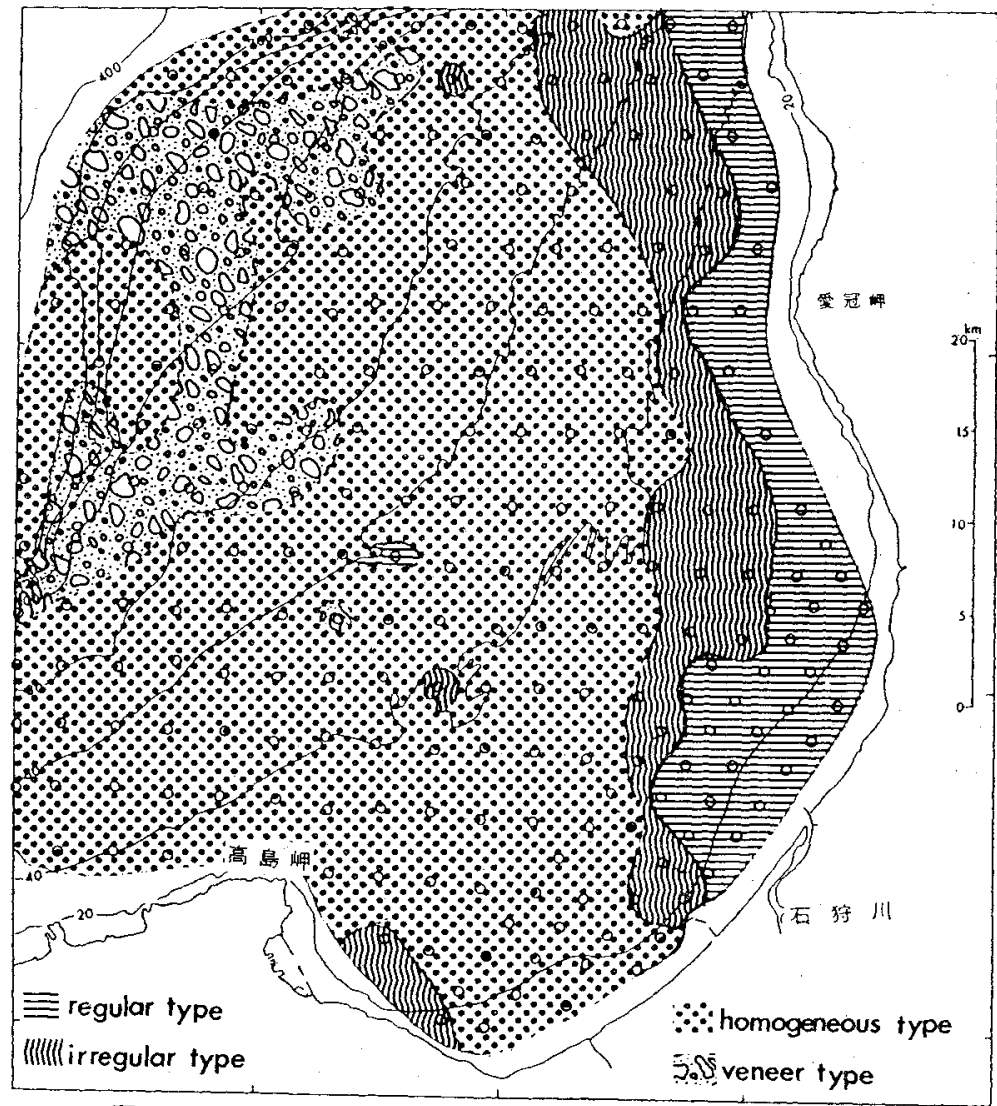

図 8 軟X線写真に上る堆積構造型の分布大嶋任 (1985)

域で，年間 $10 \mathrm{~cm}$ 以上の堆積物沈樍域化奒当する。葉理 の発達状涗は， $1 \mathrm{~cm}$ 以下の粘土之シル下の細互層する 部分と $5 \mathrm{~cm}$ 以上の居厚を有する部分々に区分され，堆 積速度変化の著しいことを示している。不規則型は，規 則型を取り巻くように分布している。底生生物の活動が 活発で，堆積物中にペレットを多産する。堆積速度は， 数 $\mathrm{cm} /$ 年位々推定さ机る。均一型の砂質堆積物は，水深 $40 \mathrm{~m}$ から $100 \mathrm{~m}$ の大陸棚の大半要得っている。水深 100 $\mathrm{m}$ 以深の泥質均一型堆積物汇は, 生瘦が斑紋状伐され ているものむある。いずれる，無爑積もしくは，間矢的 に数 $\mathrm{mm} /$ 年程度の堆積速度であるら。薄層型は，大陸 棚外縁の基盤岩委た结碩層表面を薄く覆うもので，海底 写真では露岩地域として見られる。

以上の堆積構造の特街から，もし再移動が無いとした ならば，堆積物の層厚分布は，規則型，不規則型，均一 型の順になっているはずである。しかし，実際の海底に 分布する現世堆積物の最大層厚は，15m程度にしかすぎ ない。委た，規則型分布域々堆積物厚層域とは，必ずし あ一致していない。

石狩湾の堆櫴環境を仙台湾のそれと比較検討するため

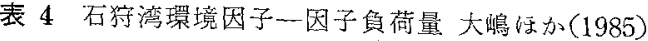

\begin{tabular}{|c|c|c|c|c|c|}
\hline \multicolumn{2}{|c|}{ 翏 } & 量 & 主成分 1 & 主成分 2 & 主成分 3 \\
\hline \multicolumn{2}{|c|}{ 水 } & 樑 & 0.479 & 0.79 & 0.164 \\
\hline \multicolumn{3}{|c|}{ 粒径中央值 } & -0.85 & 0.17 & 0.236 \\
\hline 泥 & & 湿 & -0.692 & -0.624 & -0.119 \\
\hline \multicolumn{3}{|c|}{$\mathrm{Eh}$} & 0.641 & -0.363 & 0.599 \\
\hline 濁 & & 度 & -0.863 & -0.347 & 0.041 \\
\hline \multirow[t]{3}{*}{ 軟 } & $\mathrm{X}$ & 綄 & -0.827 & -0.073 & 0.317 \\
\hline & 䟞 & & 0.649 & -0.594 & 0.074 \\
\hline & 泥 & & -0.837 & 0.487 & 0.112 \\
\hline
\end{tabular}

に，堆嫧環境因子の主成分分析を行った（表 4）。その 結果, 外洋深層水型環境( I ), 河川水型環境( II), 沿岸 水環境( III)外側大陸棚の海流系環境( N) K区分できる。 仙台湾では明らかでなかった河川水型㻴境が，石狩湾で は，かなり広範围汇分布し，它の堆積環境としての性格 が，買なることを示している(図9)。

石狩湾堆積物の起源快, 砂粒組成の主成分分析の因子 負荷量加ら，残存性堆積物。河川浮逊酳浒運搬堆皘物， 海浜系堆嫧物执よび残存性堆積物に現地性鉱物の海緑石 


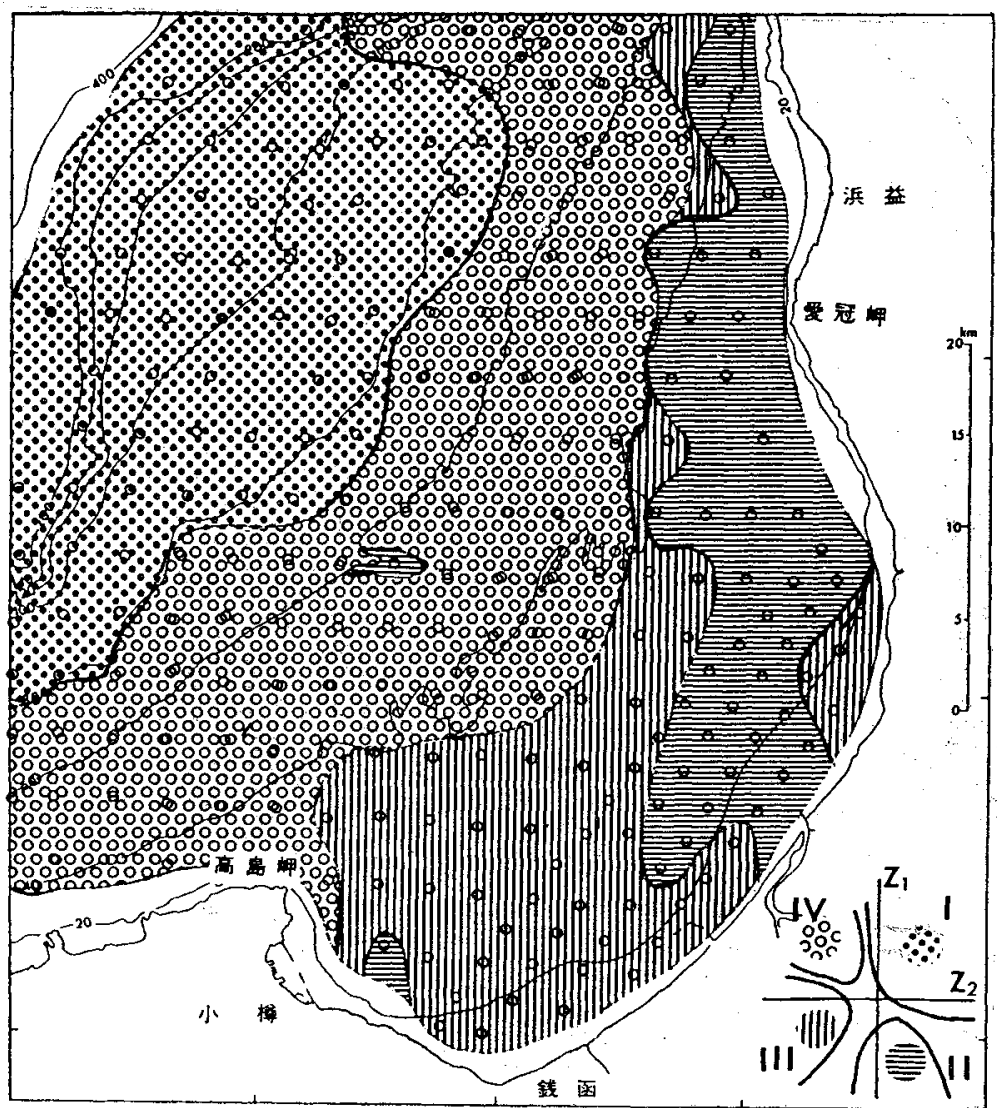

図 9 石等湾環境因子の主成分分析に上る環境区分大嶋ほか（1985）

表 5 石狩湾堆積物総括表 大嶋任办（1985）

\begin{tabular}{|c|c|c|c|c|c|c|c|c|c|}
\hline \multirow{2}{*}{ 沿 岸 $40 \mathrm{~m}$ 以浅 } & \multirow[t]{2}{*}{$\operatorname{Md} \phi$} & \multirow[t]{2}{*}{$\mathrm{C}-\mathrm{M}$} & \multicolumn{3}{|c|}{$\begin{array}{l}\text { 砂ーシルトー } \\
\text { 粘土 } \\
\text { S-S-C }\end{array}$} & 砂粒組 成 & \multirow[t]{2}{*}{ 全炭素量 } & \multirow[t]{2}{*}{ 全窒素量 } & \multirow[t]{2}{*}{ 層 厚 } \\
\hline & & & & & & & & & \\
\hline 汀 線 砂 & $3-4$ & IV. & & 砂 & & 残 存 性 & $0.5 \%$ 以下 & $0.05 \%$ 以下 & $20 \mathrm{~m}$ 以下 \\
\hline 三角州堆積物 & $3-8$ & VI or VII & 砂 & 䅡 & 泥 & 砕 触 性 II & $0.5-2 \%$ & $0.05 \%$ 以上 & $5-10 \mathrm{~m}$ \\
\hline 再移動堆積物 & $3-4$ & $\nabla$ & & 砂 & & 砕 屑 性 I & $0.5-1 \%$ & $0.05 \%$ 以下 & $5 \mathrm{~m}$ 以下 \\
\hline 大陸棚 $40 \sim 120 \mathrm{~m}$ & & & & & & & & & \\
\hline 残存堆 積物 & $1-3$ & IV & & 砂 & & 残 & $0.5 \%$ 以下 & $0.05 \%$ 以下 & $5 \mathrm{~m}$ 以下 \\
\hline 後期残留堆積物 & $1 \phi$ 以下 & I or II & 砂 & & 礫 & 残 & $0.5 \%$ 以下 & $0.05 \%$ 以下 & $1 \mathrm{~m}$ 以下. \\
\hline 大陸斜面一石狩海盈 & & & & & & & & & \\
\hline 前期残留堆積物 & & I or $\mathbb{I}$ & 泥 & 砂 & 㹡 & 残 留 性 & $0.5-1 \%$ & $0.1 \%$ 上 & $1 \mathrm{~m}$ 以下: \\
\hline 浮挨眯濁堆積物 & $5 \phi$ 以上 & VI, 䜣, T, & & 泥 & & 生物・現地性 & $1 \%$ \%上 & $0.2 \%$ 以上 & $75 \mathrm{~m}$ 以下 \\
\hline
\end{tabular}

が加わったものに区分できる(表 5 )。

石狩川から搬入されな植物片队石炭粒は，他の浮遊眊 濁粒子とともに挙動し；河口から北上する40\%以上の高 含有带と南西に下る経路との 2 つに分机る(図10)。北 上する高含有带は，愛冠岬の沖で消隇する。南西以下る ルートは，小樽沖まで延伸し，時計回りに高島岬の沖側
を通って外海へ应散している。水深 $40 \mathrm{~m}$ 以深の大陸棚上 に広く分布与る残存堆積物には，5\%以下の石炭精が含 まれるにすぎない。すなわす，浮游懸濁媈搬される石炭 粒は，開口性の大陸棚上には滞留しないで,さらに沖合 いと運び去られている。その様子は，泥分含量の分布 とも良く対応している。石岸粒を運搬する沿岸流流向 


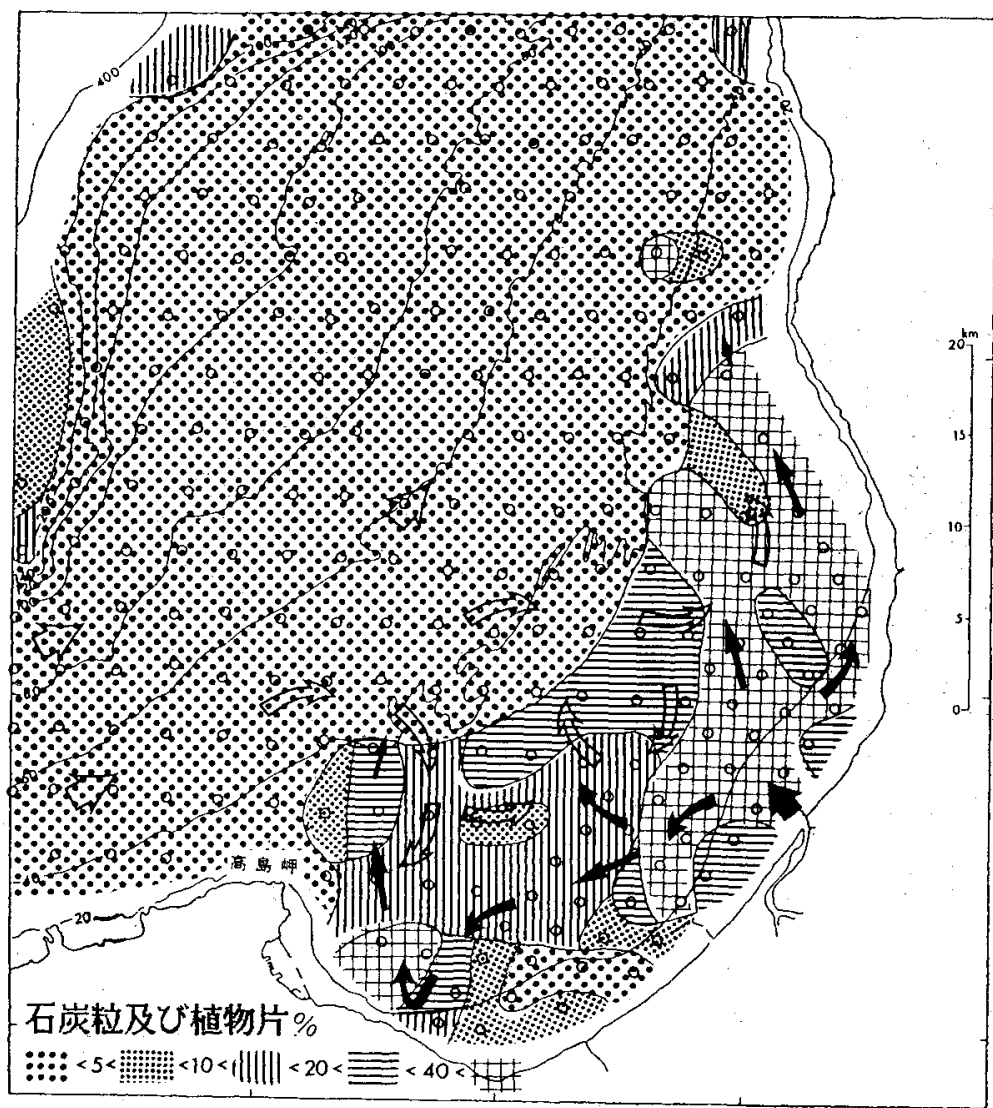

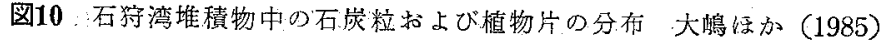

（図10白技き矢印）快，石炭粒含有量の低い海域をルトとして湾奥に向かっている。

重金属の分布状況和よびその起源を解明するために， 銅，鉛，垔鉛，ニッケル，クロム，コバルト，マンガン； 鉄の含有量をるとめた。これらの重金属, 有機物和よび 粒度組成との相関係数を基に，タラスタ一分析を行っ た。タラスタ一分析の結果 (図11)，堆積物の重金属含 有量は, 砂分と関係するマンガン, 鉄, コバルトグルー プ，泥分上関係する鉰，亜鉛グループ，粒度組成とは関 俰のないクロム、 ニッケルグループの3つに区分され る。すなわち，河川による浮遊眯濁運搬物には，銅，亜 鉛が多く，大陸棚の残存堆積物には，マンガン，鉄が多 いしたがって，本海域推積物中の銅，鉛，严鉛，二ッ ケル,クロムは陸起源でめり, 鉄, マンガン, コバルト は海水起源であることを推定させる。

\section{4 : 德火湾}

檟火湾湾口部の水深 $(91 \mathrm{~m})$ ほ, 湾央の最深部 $(107 \mathrm{~m})$ よりも浅い。そして，湾口部には，室蘭側的ら浅い靬部 地形が張り出しているため, 現海水面での湾口幅 $27 \mathrm{~km}$ が，水深 $60 \mathrm{~m}$ て $14.8 \mathrm{~km}$ 飞半減する。さらに，水深 80

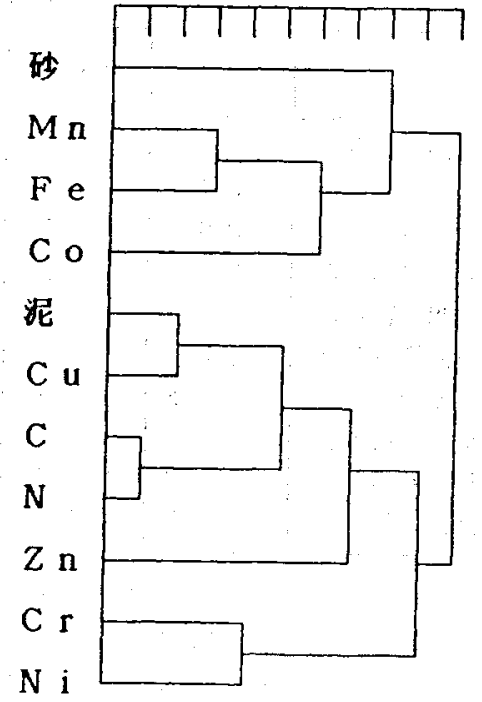

図11 石狩湾堆漬物成分のクラスタ一分析 大嶋注加（1985） 


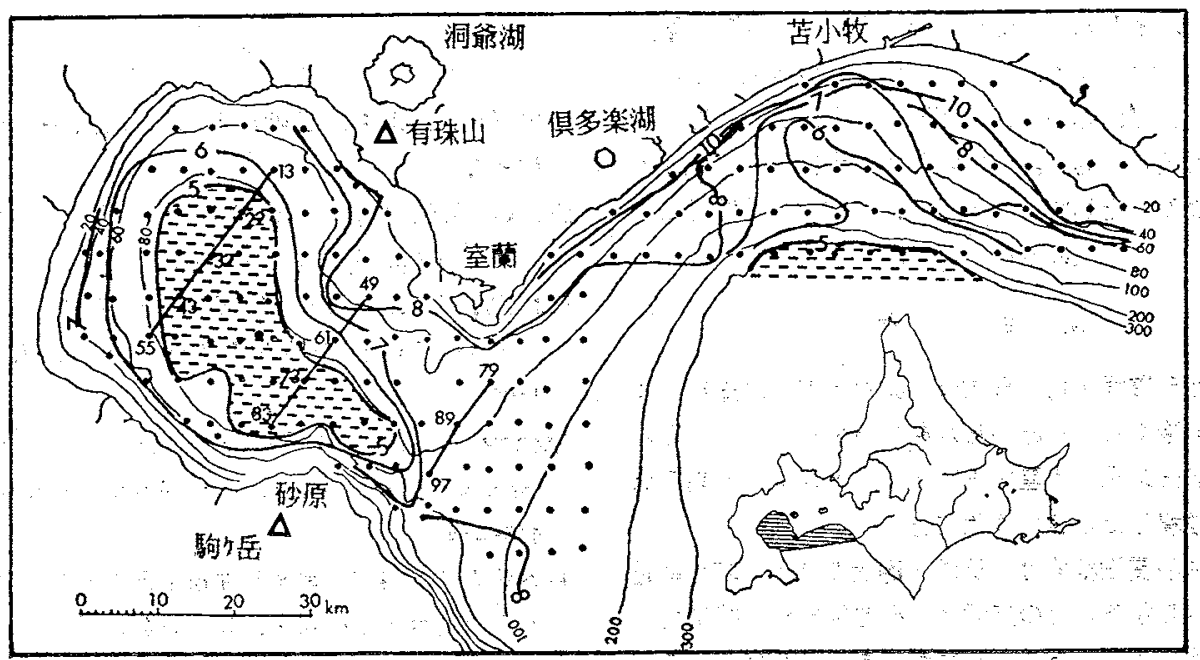

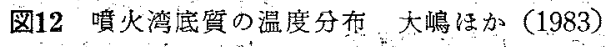
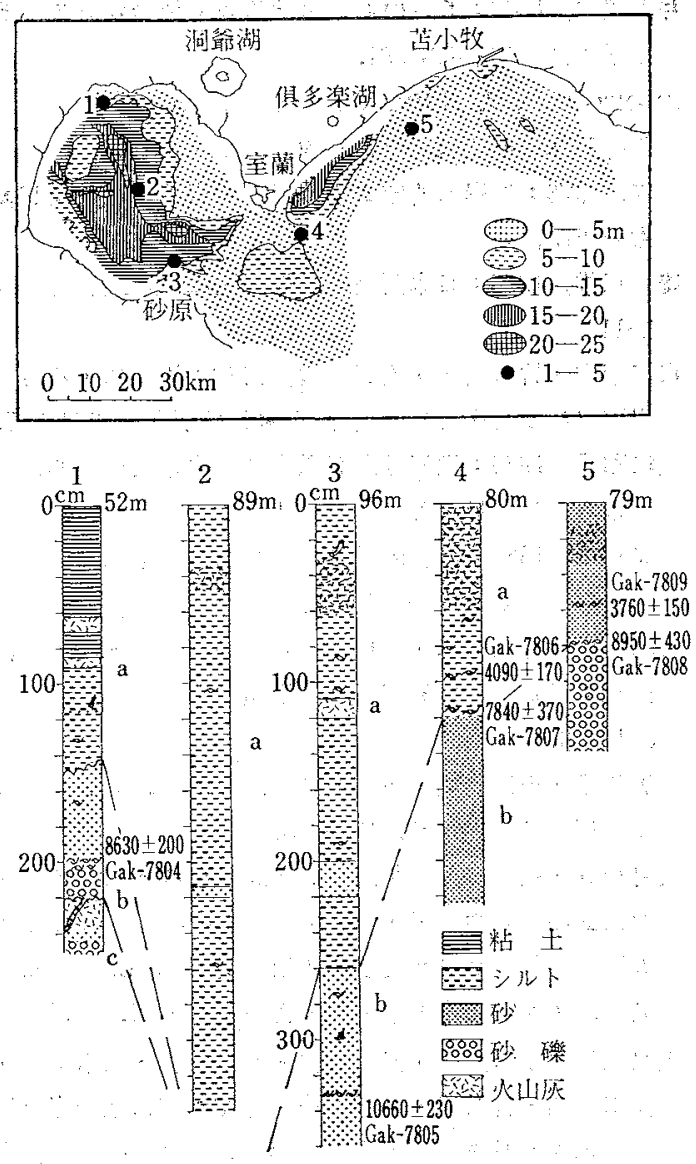

図13 噴火湾表曾堆積物吸層厚分布 大嶋注加 (1983) $\mathrm{m}$ での湾口幅は $2 \mathrm{~km}$ となり，沙央 $80 \mathrm{~m}$ 等深線の横断距 離 $16 \mathrm{~km}$ よりもか子涨い閉鎖性環境となる。永樑 $80 \mathrm{~m}$ 以深での閉鎖性環境の状馝は，噴火湾内の水樑 $80 \mathrm{~m}$ 以樑 の底質温度が，水温成層のために，苫小牧沖の水深 300 $\mathrm{m}$ 以深の底質温度と痤添同じ $5^{\circ} \mathrm{C}$ 以下以あって，具類の 分布は，この底質温度に対応している(四12)。

音響的地層探查によって，a，b，cの3層が区別でき

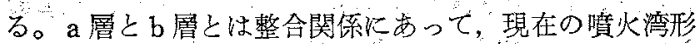
成後の海底堆積物である。a層拈よび b 層を一括した表 層堆䅡物の層厚分布は，0 mから $25 \mathrm{~m}$ 京で変化する（図 13）。 c 層は，噴炎湾の基底地形を作る音響的基盤であ る。表層堆積物の厚層域は，海底写真の濁度分布から推 定した底層流の環流域に湾济対応している。すなわち， 浮遊憅濁運搬物質である現世泥質堆積物の層厚分布は, 噴火湾の底層流系が閉鎖性環境にあるこを去してい る。

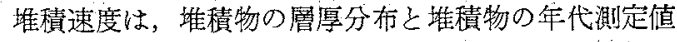
から決定さ机るが，噴出年代の判明している火山灰の産 出深度からむ求めら礼る。これらの方法によって求めた 爑積速度柱，最大 $2.5 \mathrm{~mm} /$ 年で方。海域が閉鑜性で るため，一次的な堆積速度は荤いが，它の收支淮積量は 仙台湾や石狩湾上りも大きい。

\section{5 瀬戸内海}

閉鎖性堆積環境である瀬戸内海は，富采善化化よる赤 潮被害が甚犬゙しいため，多くの調査研究が進められてい る（塩沢核か；1979，井内，1982）。瀬戸内海の大部分 恃，水深 $60 \mathrm{~m}$ 以浅の平坦な灘地形がらなるが，灘已灘と を結ぶ瀬戸（海峡）には，潮流漫食にようて形成された 海釜地形が発達している（小野寺・大鳰，1983)。表層 堆積物の層厚分布は，灘に搬入される堆積物量によって 
決定される。すすすわち，淀川の流入する大阪湾，“吉野 川，紀ノ川の流入する紀伊水道，太田川の流入する広島 湾では，堆積層は厚いが，河川流入の少ない周防灘，伊 予灘での婎積物は薄い。厚い堆積物の大部分は，泥質堆 積物からなる。そして，海陕付近に分布する砂筫堆㱴物 の起源は，海底浸食に求められる。

\section{5. まとめ}

1，現世砂質堆積物の分布は，瀬戸内海の水道部のよ うな海域を除くと，汀線から水深 $15 \mathrm{~m}$ 付近までに限られ る。水深 $40 \mathrm{~m}$ 以深の大陸棚上飞分布する砂は，米期の低 海面期に爑積した残存堆積物である。

2. 沿岸砂質倠積物は，比較的淘汰の良い，超躍動運 搬堆積物からなる。その起源は, 砂料組成から後背地の 地質に支配されていることが明がである。したがって， 特街的な砂粒子を追跡することによって，底層流の流向 を求めることもできる。

3. 石狩川の洪水堆積物の上5に，一度に $8 \mathrm{~m}$ 以上も 堆積することがある。また，沿岸漂仯帯では，季節的に 数 $\mathrm{m}$ の海底地形变化が見られる程変化するのが普通であ る。大陸棚上の残存堆積物む再移動して，サンドウェー ブを形成し，李節的に数 $\mathrm{m}$ 単位て变化することもある。

4. 砂粒子の運搬様式は, 粓度組成户堆積構造, 爑積 物の形成する海底微地形から推定される。李た，水理観 測データから作成した水理モデルからる推諭できる。

5. 堆積物の空間的な広がりは，音波探査によって求 められるが，浅海域では，海底面の多重反射やノイズに よって，あまり良い記録はと执ない。したがって，海岸 平野のボーリング資料や，海水準変動論にもとずく浸食 基準面を用いて推論しなければならない。現在の海底に 堆積する砂質堆積物の厚さは，海岸平野を流れる川の河 床底最大深度に㴗济対応する。乙かて，瀬户内海の上う に，低海面時に形成された凹地を埋積する場合は，局所 的に $40 \mathrm{~m}$ を超光る場合もある。

6. 外洋性の沿岸環境で，現世堆積物の堆積速度を決 定することは，再移動が激しくて難しい。たとえば，堆 積構造から推定される一次的な沈積量と, 音波探查で求 めた堆積物厚層域とは，必ずしも一致しない。だが，噴 火湾や瀬戸内海のような，稳やかな海域での泥の堆積速 度は，音波探査拉よび堆積構造解析の結果と良く一致す る。

7. 堆積物の分布を基本的に支配しているのは，第四 紀後期以降の海面変動比って形成されてきた沿岸地形 （推積盆の形態）である。

\section{参考文 献}

有田正史，1981：海虚細骨材の話。地質 $=ュ ー ス, 320$, $18-28$.

DAvIS, A.D. Jr., 1978: Coastal Sedimentary Environments. 420p. Springer-Verlag.

EMERY, K.O., 1952: Continental shelf sediments of southern California. Geol. Soc. Am. Bull. 63, 11051108.

EMERY, K.O., 1968: Relict sediments on continental shelves of the world. Am. Assoc. Pet. Geol. 52, 445-464.

長谷弘太郎，1967：宮城県沖積平野の地質学的研究. 東 北大地質古生物研邦報， 64, 1-45.

早坂一郎, 1964 : 潮間带に扣ける生態学之堆積学. 地学 雑誌, 73, 351-365.

井内美郎，1982：瀬亞内海に扣ける表層堆積物分布. 地 質学雑誌, 88, 665-681.

JoHnsoN, D.W., 1919: Shore Processes and Shoreline Development. 584 p. John Wiley and Sons. 金绮 肇 訳, 1976 : 海岸に於ける諸作用と海岸線の発達. 548p. 古今書院.

淸 正雄, 1966 : 日本列島の最後の陸橋. 地球科学, 85, $2-11$.

森田康志・竹本成行・牧野成雄, 1982 ：洪水に上る石特 川河口部の变形とその復元士末試験所月報, 354,2-6. 大嶋和雄，1976：洪積世末葉以降の海水準変動. 北海道 考古学，14，11-22.

大嶋和雄，1980：海陕地形心記された海水準变動の記 録. 第四紀研究，19，23-37.

大鸩和雄 - 井上英二 - 小野寺公罗 - 湯浅真人 - 黑田敬, 1982：刘馬一五島周辺海域の堆積物. 地調月報, 33, $321-350$.

大嶋和雄・横田節哉, 1983 : 噴火湾の地形, 地質, 沿岸. 海洋研究ノ一ト. 20, 189-203.

大嶋和雄 - 横田節哉・井内美郎 - 鈴木泰輔 - 松本英二・ 池田国昭・村瀬 正・羽坂俊一，1985：開口性沿岸海 域開発に伴 5 底質活染予測技術に関する研究一石狩 湾一。昭和59年度国立機関会害防止等研報. 64, 1-32. 大嶋和雄・横田節哉・斎藤文紀、鈴木泰輔・松本英二・ 池田国昭・村瀬正・羽坂俊一, 1986：開口性沿岸海域 開発に伴 5 底質污染予測技術に関する研㠰一仙台 湾一。昭和59年度国立機関公害防止等研報。 54, 1-28. 小野寺公児 - 大嶋和雄, 1983 : 瀨户口海東部海域の地形 発達史。地調月報， 34，217-239.

PASSEGA, R,, 1964: Grain size representation by CM 
patterns as a geological tool. Jour. Sediment. Petrol., 34, 830-847.

REINECK, H.E., and SINGH, I.B., 1973: Depositional Sedimentary Environments. 439 p. Spinger-Verlag.

SHEPARD, F.P., 1932: Sediments on continental shelves. Geol. Soc. Am. Bull., 43, 1017-1034.

SHEPARD, F.P. and MOORE, D.G., 1954: Sedimentary environments differentiated by coarse-fraction studies. Am. Assoc. Pet. Geol. Bull., 38, 1792-1802. 塩沢孝之・川名吉一郎・星加章 - 谷本照巳 - 潼村修,
1979 : 瀬戸内海の底質. 中工試報告, 4，1-24.

SWIFT, D.J.P., KOFOED, J.W., SAulsbury, F.P., and SEARS, P., 1972: Holocene evolution of the shelf surface, central and southern Atlantic coast of North America. In SwIFT, D.J.P., DUANE, D.B., and PILKY, O.H. eds., Shelf Sediment Transport: Process and Pattern. 499-574. Stroudsburg, Dowden, Hutchinson \& Ross

TRASK, P.D., 1935: Recent Marine Sediments. 736 p. Thomas Murby \& Co. 